\title{
環境共生機能に配慮した新型ブロックの 効果検証現地調査
}

\author{
廣瀬 紀一 1 - 柴田 早苗 2 - 若林 信孝 1 - 昇 悟志 $3 \cdot$ 三井 順 4 - 浜口 正志 5 \\ 1(株)不動テトラ ブロック環境事業本部技術統轄部（テ103-0016 東京都中央区日本橋小網町7-2） \\ E-mail:norikazu.hirose@fudotetra.co.jp \\ E-mail:nobutaka.wakabayashi@fudotetra.co.jp \\ ${ }^{2}$ (株)不動テトラ ブロック環境事業本部東京技術部（テ103-0016 東京都中央区日本橋小網町7-2） \\ E-mail:sanae.shibata@fudotetra.co.jp \\ ${ }^{3}$ (株)不動テトラ 総合技術研究所（テ300-0006 茨城県土浦市東中貫町2-7） \\ E-mail:satoshi.noboru@fudotetra.co.jp \\ 正会員 (株)不動テトラ 総合技術研究所（テ300-0006 茨城県土浦市東中貫町2-7） \\ E-mail:jun.mitsui@fudotetra.co.jp \\ 5正会員 (株)不動テトラ ブロック環境事業本部北陸技術部 \\ ( (950-0078 新潟県新潟市中央区万代島5-1) \\ E-mail:masashi.hamaguchi@fudotetra.co.jp
}

近年の港湾，漁港，海岸施設の整備では，環境や生物との共生が求められる。これらの施設に用いられ る消波ブロックや被覆ブロックには, 海藻類の着生が期待されるが, 従来のブロックは海藻類の着生を考 慮した形状ではなく, 藻場の形成に強く寄与寸るものではなかった。 そこで, 従来のブロックと同等以上 の安定性, 水理機能を有し, 環境共生機能, 特に海藻類の着生に配慮した形状の消波ブロック並びに被覆 ブロックを開発した。 これらのブロックの環境共生機能を把握するために，全国で現地調查を実施した。 その結果，調査実施箇所すべてにおいて，カジメやアラメ等の大型海藻の着生が観察された。さらに，ア ワビ, サザエ等の魚介類の蝟集も観察された.

Key Words : eco-friendly, seaweed bed, fish shelter,wave dissipation block, armor block

\section{1. はじめに}

近年の環境意識の高まりにより，港湾，漁港や海岸の 施設整備にあたっては，環境や生物との共生に配慮する ことが不可欠となってきている.これらの施設整備に用 いられる消波ブロックや被覆ブロックが設置される水深 帯は，海藻類が着生する水深帯と一致していることが多 く, 消波ブロックなどに海藻類が着生し, 藻場が形成さ れた事例が報告されている11. しかし，これら従来のブ ロックは防災機能を目的に開発されており, 海藻類の着 生を考慮した形状ではない. そのために, 藻場の形成, すなわち，海洋環境の保全・再生に強く寄与寸るもので はなかった，そこで，著者らは，従来のブロックと同等 以上の而波安定性，水理機能を有し，環境共生機能，特 に海藻類の着生にも配慮した消波ブロックおよび被覆ブ ロッグを開発した。
藻場の形成や魚介類の蝟集などの環境共生機能の効果 を確認するためには，現地での調査が必要である．新型 消波ブロックは平成22年, 新型被覆ブロックは平成21年 に現地での設置が開始された，各地で環境共生機能の検 証を目的に調查を実施したところ，海藻類の着生や魚介 類の蝟集が観察されたので，以下に報告する.

\section{2. 新型ブロックの形状検討}

日本の沿岸域において，藻場を構成する種として水産 有用種のコンブ類やアラメ，カジメなどのコンブ科海藻， ホンダワラ類などの大型海藻類, さらにはテングサ類な どがあげられる.コンブ科海藻は，天然岩礁の凸部やブ ロックの稜線部に着生しやすいこと3ややカジメの固着力 は，ブロックの稜角部に着生していた個体のほうが，平 

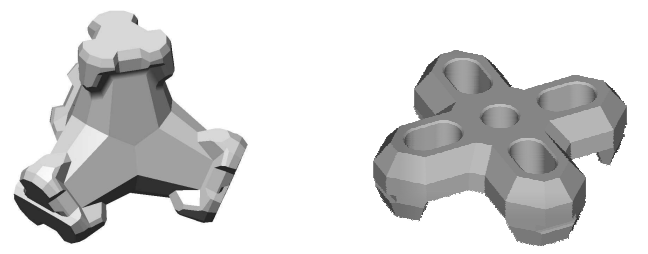

図-1 新型消波ブロック

（左）と新型被覆ブロック（右）

坦部の個体よりも大きい傾向にある4)ことが報告されて いる．海藻類の生長には光が必要であり，太陽光の当た る稜線が長ければ, これらの海藻類の着生に有効である。 そこで，新型ブロックには長い稜線を持たせることと した．開発した新型消波ブロックと新型被覆ブロックを 図-1に示す.

一方，魚介類の蝟集には，これら生物の生息空間が広 いこと，およびその空間が複雑であれば，生物量と生物 種が豊富になると考えられる．新型消波ブロックの空陌 率は60\%であり，従来のブロックに比べて大きく，生物 生息空間が広い. また，脚部が突起形状となっているた め, 形成される空間が複雑になり，多様な生物の利用が 想定できる．新型被覆ブロックは，大きな開口部が生物 の生息空間として利用でき, 脚が高いため, 海底面とブ ロック底面との空間も魚介類が利用できるものと考えた. なお，新型ブロックの而波安定性，水理機能や構造強 度は，水理模型実験や数值解析などにより従来のブロッ クと同等以上であることを確認している.

\section{3. 新型ブロックの現地調査}

現地調査は図-2に示す4力所で行った.

\section{(1) 新型消波ブロックの現地調査}

\section{a) 茨城県茨城港日立港区}

平成22年9月に茨城県茨城港日立港区第3 手頭の護岸の 消波工前面に新型消波ブロック $4 \mathrm{t}$ 型4個を試験的に設置 した。ブロック設置箇所の水深は約 $3 m$ である（図-3）. ブロック設置箇所周辺はコンブ科海藻のアラメが多く見 られる場所である.

調査は平成24年2月（第1回）と6月（第2回）の2回行 った．第1回調査では，潜水士により4個の新型ブロック に着生したアラメの着生個体数と全長の長い上位3個体 の計測およびアラメのブロックへの着生部位の観察を行 った．第2回調査では，ブロックを陸上に引き上げ，第1 回調査と同内容の調査を陸上で行った.

図-4にブロックに着生したアラメの個体数の推移を示 す.ブロックにはアラメが優占した状況であった（図一 5）. 第1回調査では，ブロック 1個あたり36〜61個体,

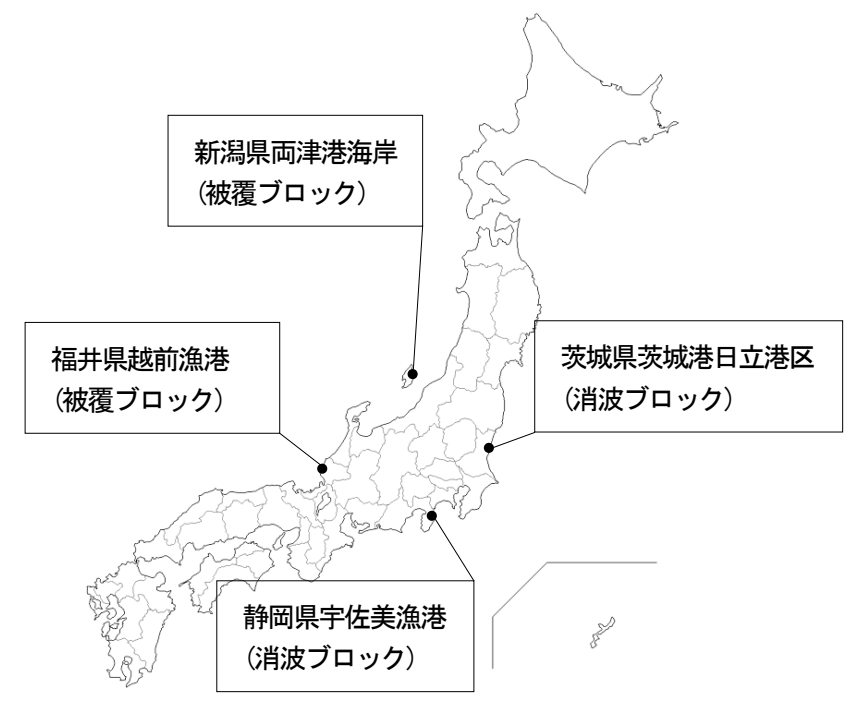

図-2 現地調査実施箇所

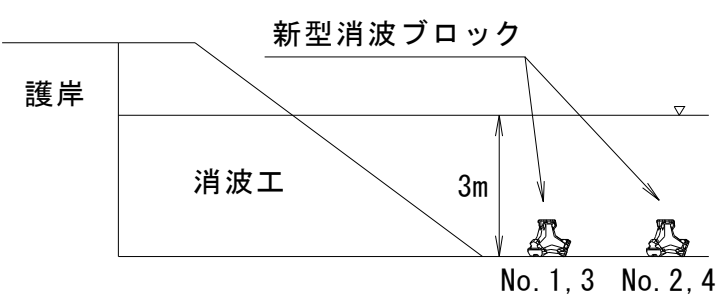

図-3 ブロック設置模式図

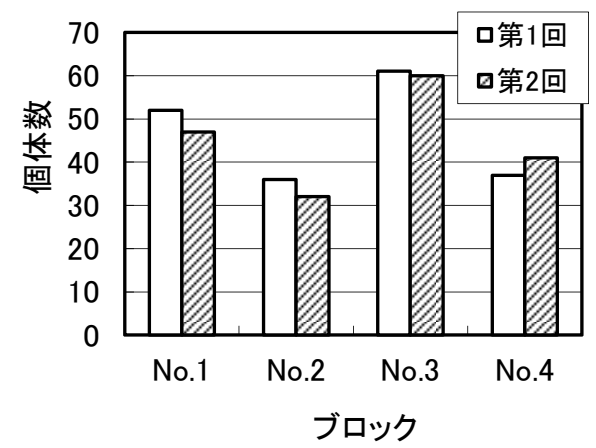

図-4 アラメの着生個体数の推移

第2回調査では32～60個体の着生が見られた. No.1とNo.3 の個体数が多いのは，アラメの胞子の供給源となる護岸 消波工に距離が近いためと考えられる. No.4を除いて, 第1回調査と比較して，第2回調査時の方が個体数が少な い.これは，一般に2月から6月にかけて，アラメの新規 加入が無い時期なので，自然減耗による減少と考えられ る. 一方，No.4の増加については，2月の調査時には葉 長が小さく，観察できなかった個体が6月には観察でき た結果と考えられる. 図-6にブロックに着生したアラメ の全長上位3個体の平均值を示す. 第1回調査では69～88 $\mathrm{cm}$ ，第2回調査では93〜 $123 \mathrm{~cm}$ であった. アラメは夏の 終わりに末枯れし，晚春から初夏にかけて著しく生長す $ろ^{5)}$. 今回の調査でも, 第1回調査から第2回調査にかけ 


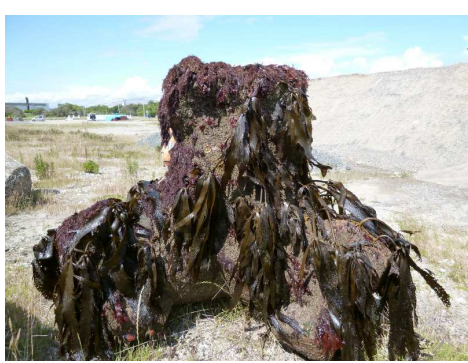

図 -5 新型消波ブロックへの海藻着生状況

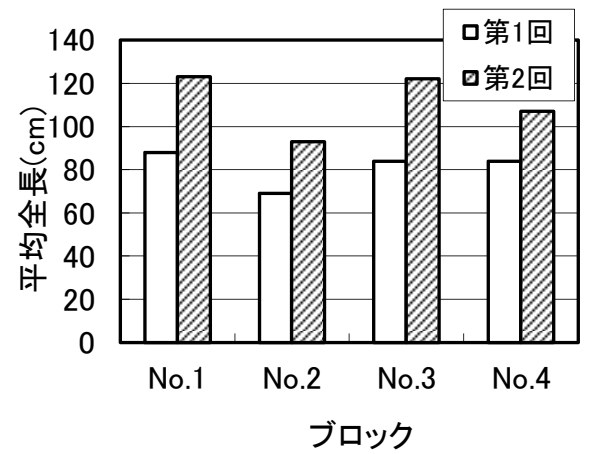

図-6 アラメの全長上位3個体の平均值の推移

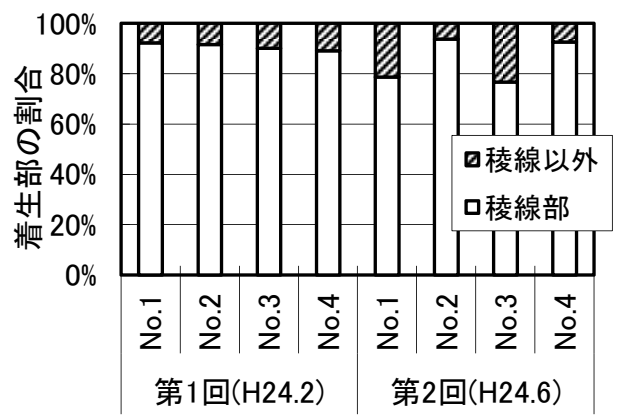

図-7 アラメの部位別着生個体数の割合

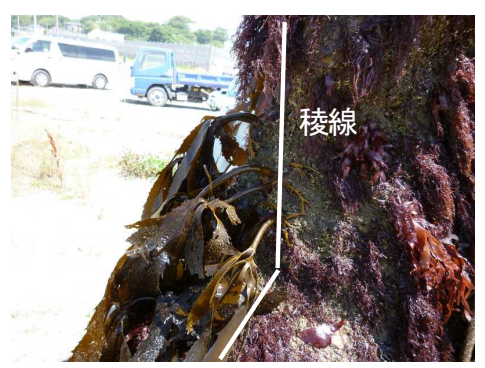

図-8＼cjkstart稜線部へのアラメ着生状況

て平均全長が増加しており，順調な生長が観察された。

図-7にブロックの部位別にみたアラメの着生個体数の 割合を示す．稜線部に着生したアラメの個体数の割合は, 全体の $77 \%$ \% $94 \%$ と高く，開発時に想定したブロック稜 線部の海藻類着生効果が示されている. 稜線部へのアラ メの着生状況を図-8に示寸.

なお，魚介類ではアワビ（図-9），ウニ，ホヤ類等の 生息が観察された.

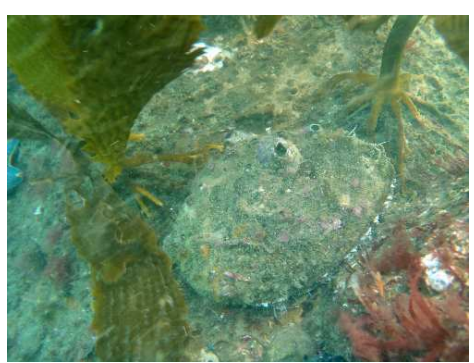

図-9＼cjkstart新型消波ブロック上のアワビ

\section{b) 静岡県宇佐美漁港}

宇佐美漁港は静岡県伊豆半島に位置する漁港である. 防波堤改良工事において，新型消波ブロック20t型が用 いられ，平成23年2月～3月にかけて施工された．宇佐美 漁港周辺は，カジメが繁茂する優良な藻場が形成されて おり，新型消波ブロックへのカジメの着生が予想された.

調查は平成24年6月（第1回），平成25年2月（第2回）, 7月（第3回）に実施した．図-10に示すよう，調査測線 を2本設定し，海底から水深 $1 \mathrm{~m}$ 毎（図-11）に50×50 cm の方形枠をブロックに当て, 枠内に着生しているカジメ の個体数を測定した. また，全長の長い上位 3 個体の計 測も行った．なお，方形枠を当てる位置は，新型消波ブ ロックの特長である稜線部を含むように選定した．カジ メ以外に着生している海藻類および生息している魚介類 の観察もあわせて行った。

カジメの着生個体数を図-12に示寸. 第1回調査では, 測線1が8〜16個体 $/ \mathrm{m}^{2}$ （第1回調査の水深 $4 \mathrm{~m}$ は未測定），

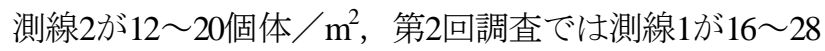
個体 $/ \mathrm{m}^{2}$ ，測線 $2 か ゙ 20 \sim 136$ 個体 $/ \mathrm{m}^{2}$ ，第3回調查では測 線1が12〜64個体 $/ \mathrm{m}^{2}$ ，測線 $2 か ゙ 8 \sim 12$ 個体 $/ \mathrm{m}^{2}$ の着生個 体数であった. 概敉, 各水深とも第1回調査から第2回調 查にかけ着生個体数が増加し，第3回調査では減少する 傾向にあった．これは，第1回調査後の平成24年秋にカ ジメの胞子が放出され，翌年の第2回調查時に幼体が確 認されたためで，その後の生長に伴い，個体数が減少し たものと考えられる．特に，第2回調査の測線 2 の水深

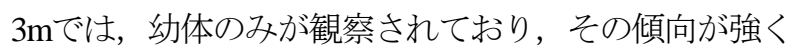

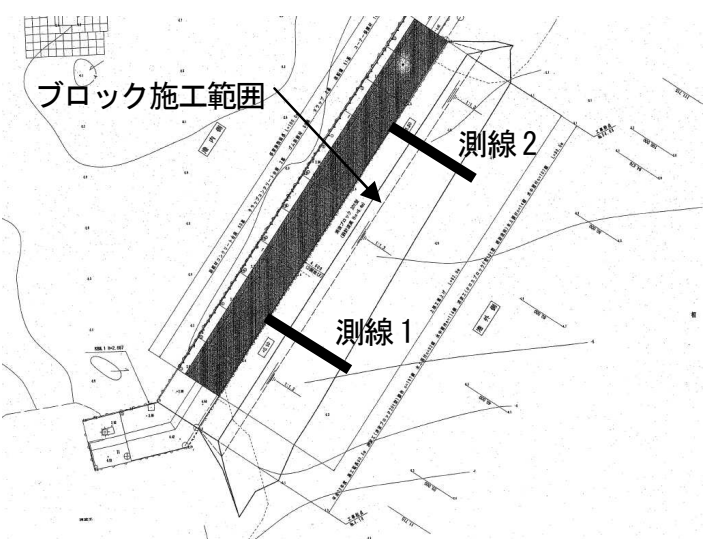

図-10 調査測線図 


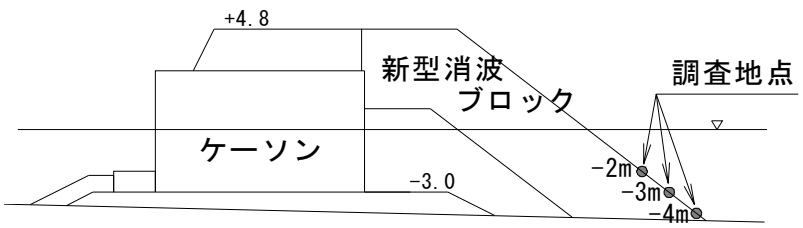

図-11 調査地点模式図

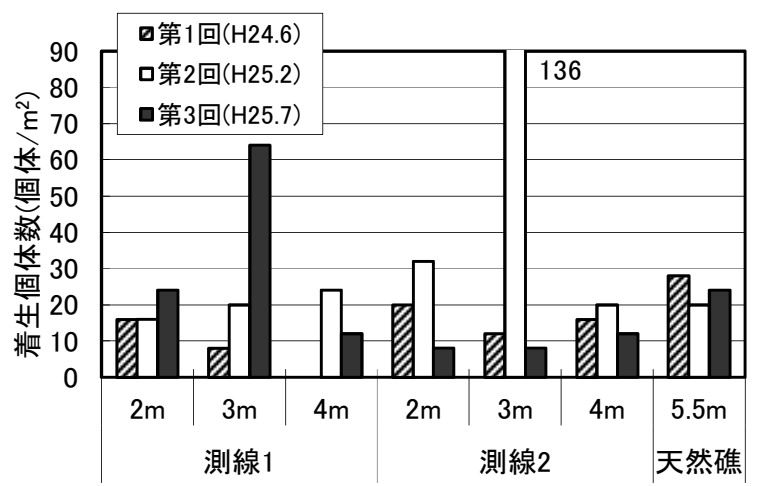

調査測線と水深

図-12 カジメの着生個体数の推移

見られた。測線1の水深 $3 \mathrm{~m} て ゙ は$ 第3回調査時の個体数が 最も多いが，その理由は不明である。なお，カジメの全 長上位3個体の平均值は, 第1回調查時が $20 \mathrm{~cm}$ 前後, 第2 回調査では10 $40 \mathrm{~cm}$ 程度, 第3回調査では $30 \sim 50 \mathrm{~cm}$ 程度 であった。これらのカジメはブロックの稜線部や突起部 に着生している個体が多く（図-13），前述の茨城港日 立港区と同様，ここでも新型ブロックの形状の効果が確 認された。

ブロック設置箇所近傍の天然岩礁の水深 $5.5 \mathrm{~m}$ における カジメの個体数は, 第1回調査から第3回調査を通じて, 20〜28個体 $/ \mathrm{m}^{2}$, 平均全長は70 $80 \mathrm{~cm}$ 程度であった. ブロック上のカジメの個体数は, 天然岩礁と概初同程度 であるが，平均全長は小さい，これは，ブロック上のカ ジメは大きくても2年齢の個体であるのに対して，天然 岩礁のカジメは3年齢以上であるためであり，今後は全 長も天然岩礁と同程度になっていくものと考えられる.

カジメ以外の海藻類では, ホンダワラ類, ワカメ, テ ングサ類などが観察された。 魚介類ではネンブツダイや メジナの群れやイシダイなどが観察され, 新型ブロック が魚礁の効果を発揮していると考えられた. サザエの生 息も観察され（図-14），豊かな生物相が形成されつつ あることが確認できた.

\section{（2）新型被覆ブロックの現地調査}

\section{a) 福井県越前漁港}

平成21年10月〜11月に新型被覆ブロックが福井県越前 漁港の城ヶ谷地区の北防波堤マウンドの被覆材として, 4t型が設置された（図-15）。周囲の天然岩礁には，ク

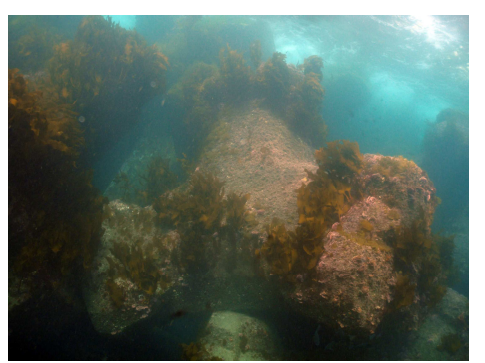

図-13 稜線部へのカジメの着生状況

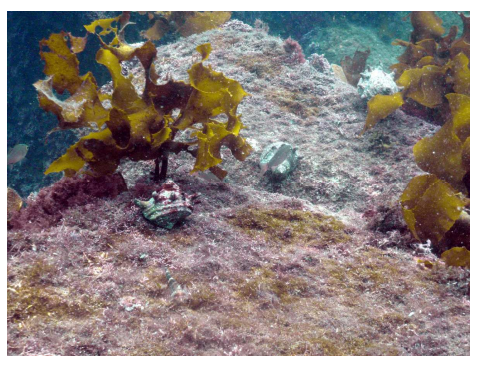

図-14 新型消波ブロック上のサザエ

ロメとホンダワラ類が混生した藻場が形成されている. 平成22年4月から平成24年11月までに4回の調査を実施し た．調査では，港内側に1測線を設定し，図-15に示す調 査対象ブロックに着生した海藻類の被度（ある種が一定 の面積内で占める投影面積の割合）や個体数の測定，蝟 集している魚介類の観察を目視にて行った.

平成22年4月（第1回），平成22年9月（第2回）の調査 ではコンブ科海藻のクロメの幼体が優占して着生してい るのが確認された。 ここでは，クロメが2年齢以上の個 体となった平成23年10月（第3回），平成24年11月（第4 回）の調査結果について示す.

各ブロックに着生したクロメの個体数を図-16に示す. 第3回調査ではブロック1個あたり 34～256個体，第4回調 査では16〜105個体のクロメの着生が見られた. ブロッ クNo.1〜No.5の設置水深は10m以浅であり，この水深帯 にクロメの着生が多い傾向が見られた（図-17）。表-1 にクロメとホンダワラ類の被度観察結果を示す。第3回 調査ではクロメの被度が高く，ホンダワラ類の被度は低 い.この時のホンダワラ類は小型の個体であった. 第4 回調査では逆にホンダワラ類の被度が高く, クロメの被 度が低い.ブロックの設置時期がクロメの成熟期に一致 していたため，クロメが先に着生し，当初はクロメが優 占する藻場であつたのが，寿命が $2 \sim 5$ 年程度のクロメが 世代交代の時期を迎え，ホンダワラ類が入植，生長し， クロメ, ホンダワラ類が混生した藻場へと遷移してきた ものと考えられる. このように着生する海藻類の種類数 も増加し, 多様性が増加してきている.

クロメのブロックの着生部位に着目した個体数を図一 18に示す.ブロックの稜線部に着生したクロメの割合は, 第3回調査では設置水深の深いブロックで低い值がある 


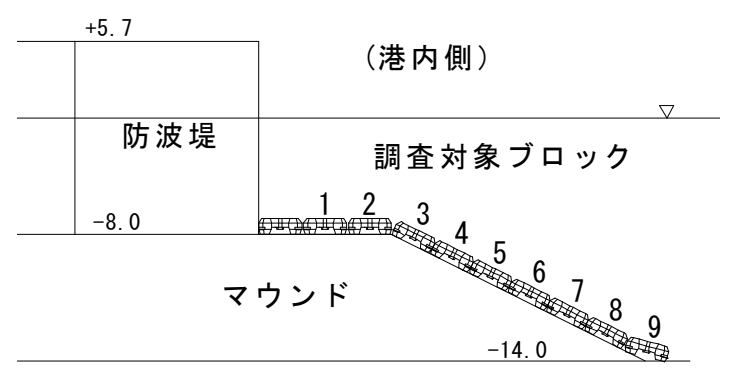

図-15 越前漁港城ヶ谷北防波堤断面模式図

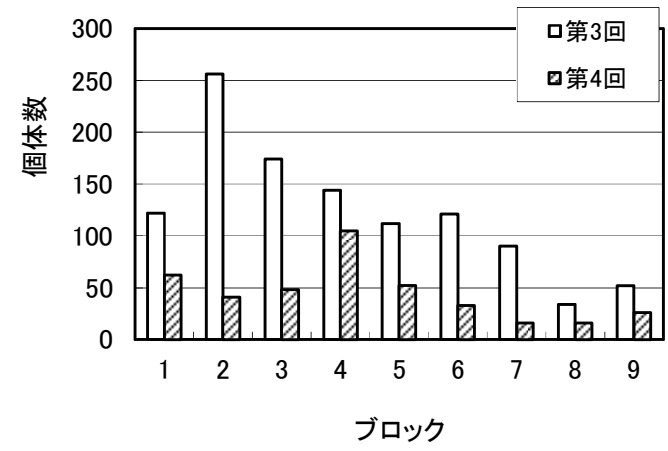

図-16 クロメの着生個体数

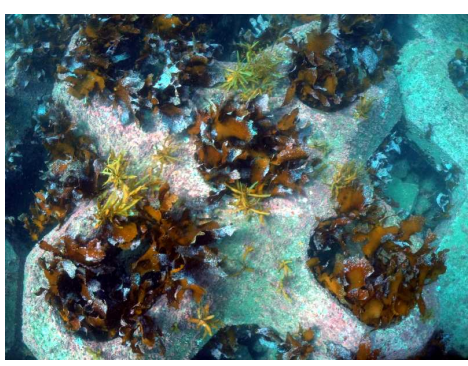

図-17 クロメの着生状況

表-1 クロメとホンダワラ類の被度観察結果

\begin{tabular}{|c|c|c|c|c|}
\hline \multirow{2}{*}{$\begin{array}{c}\text { ブロック } \\
\text { No. }\end{array}$} & \multicolumn{2}{|c|}{ クロメ } & \multicolumn{2}{c|}{ ホンダワラ類 } \\
\cline { 2 - 5 } & 第3回 & 第4回 & 第3回 & 第4回 \\
\hline 1 & 20 & 10 & 10 & 60 \\
\hline 2 & 50 & 30 & 10 & 30 \\
\hline 3 & 70 & 20 & 10 & 40 \\
\hline 4 & 40 & 20 & 10 & 50 \\
\hline 5 & 10 & 10 & 10 & 60 \\
\hline 6 & 5 & 10 & 20 & 50 \\
\hline 7 & 5 & 10 & 20 & 10 \\
\hline 8 & 5 & 10 & 5 & 5 \\
\hline 9 & 10 & 20 & 5 & 40 \\
\hline
\end{tabular}

単位: \%

ものの，平均では $55 \%$ 以上の割合となっており，ブロッ クの形状の効果がみられた。第4回調査では平均で $50 \%$ 程度であった。 これは，クロメの幼体が稜線部以外にも 多く着生していたためである. クロメと同じコンブ科の カジメの幼体は，基質表面全体に均一に着生すること， 隅角部に付着したカジメは流出しにくいことが観察され ている゚。.クロメも同様と考えられ，今後は稜線部に着

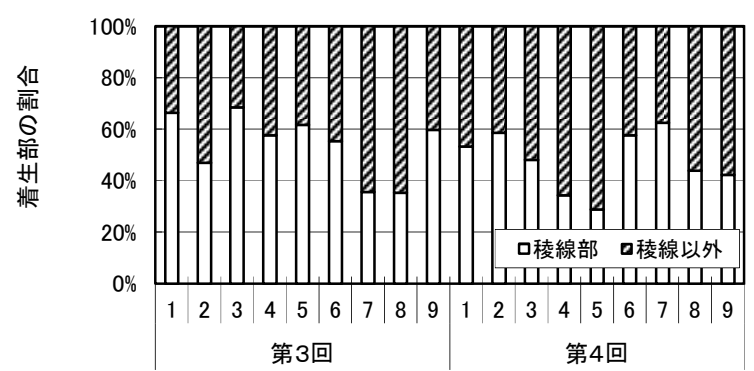

図-18 クロメの部位別着生個体数の割合

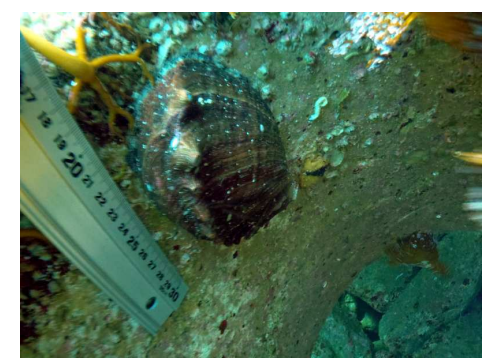

図-19 新型被覆ブロック開口部内のアワビ

生した個体の割合が，相対的に高くなっていくものと考 えられる.

新型被覆ブロックの特長である大きな開口部にはアワ ビ（図-19）や巻貝類の生息が観察され，期待通りに魚 介類の蝟集効果がみられた。

\section{b) 新潟県両津港海岸}

新潟県佐渡市の両津港海岸では浸食対策として人工リ 一フが施工されている。この人工リーフに新型被覆ブロ ック $4 \mathrm{t}$ 型が用いられ，平成22年秋季に設置された，当海 域はホンダワラ類が優占するガラモ場が形成されている。

調査は，平成23年6月より年1回，これまでに3回の調 查を実施した. 図-20に示すように，人工リーフに3測線 を設定し，各測線の沖側，堤体中央，岸側のブロックを 調查対象とした. 調查対象のブロックにおいて, 目視観 察を行い，着生している海澡類の被度を測定した.

平成23年6月の第1回調査では, 設置後の経過年月が浅い ことから，海藻類はウミウチワやアオサ類がわずかに見 られる程度であった. 3回の調查とも, 測線による植生 の大きな違いは見られなかったので，3測線の被度を平 均した沖側のブロックの平成24年5月（第2回）と平成25 年6月（第3回）の調查結果を図-21に示す．第2回調査で は全体的に被度は小さく, フクロノリなどの小型海藻が 多いが，第3回調査ではホンダワラ類の被度が $80 \%$ と高 くなり, 藻場の形成が見られた. ホンダワラ類はブロッ ク等の稜線部より平面部に着生することが報告されてお $り^{4)}$ ，当調査でもホンダワラ類がブロックの平面部に着 生しているのが観察された（図-22）。新型被覆ブロッ クは，稜線が多く，平面部は少ない形状ではあるが，木 


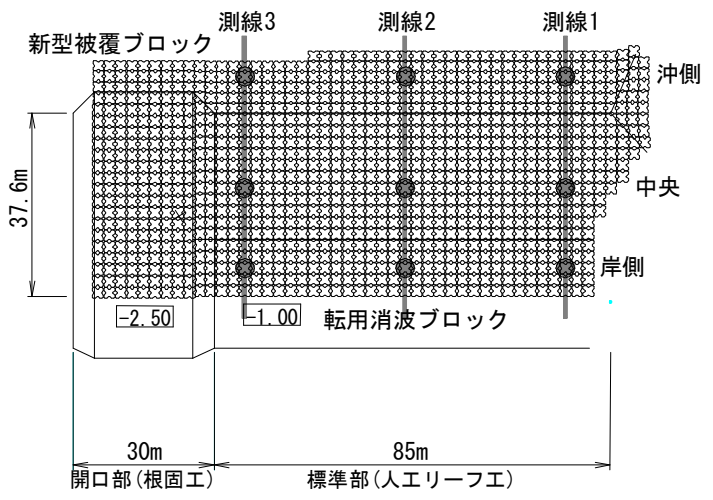

図-20 調査対象ブロック

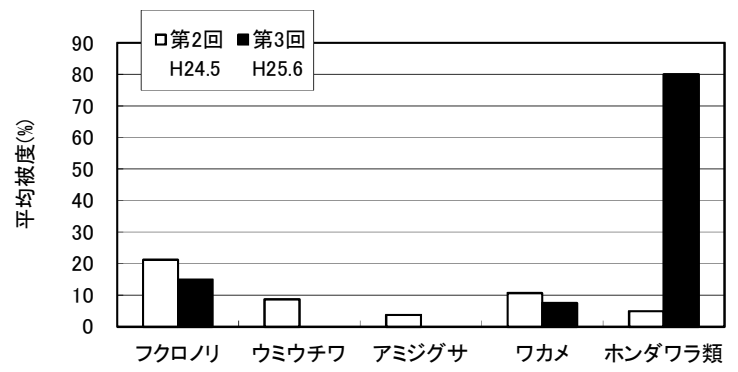

図-21 人工リーフ沖側の被度調査結果

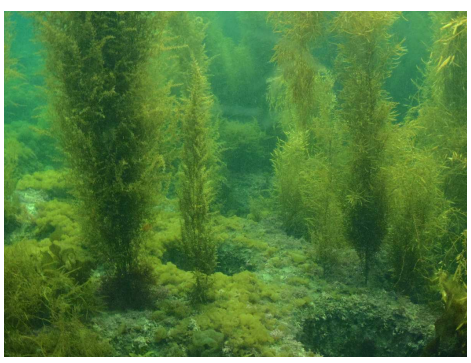

図-22 ホンダワラ類の着生状況

ンダワラ類の着生も望めるブロックであることが示され

た. また，ブロックの開口部にはサザエの生息やアイナ

メ，メバルなどの魚類が見られた.

人工リーフが施工された箇所は砂地であるが，新型被
覆ブロックを用いることで，岩礁性の生態系の早期形成 に寄与することが可能になると考えられる.

\section{4. おわりに}

海藻類の着生や魚介類の蝟集などの環境共生機能に配 慮した消波ブロックおよび被覆ブロックを開発した．実 海域に設置されたブロックの環境共生機能を把握するた めの調査を行ったところ, アラメやカジメ， ホンダワラ 類などの大型海藻の着生，アワビ，サザエなどの生息や 魚類の蝟集が見られ，環境共生機能が発揮され始めてい ることが確認された。 これらのブロックの利用によって， 今後の港湾等での構造物と環境との共生に一層の貢献が できるものと考える.

\section{参考文献}

1) 武藤昭光, 外崎昭男：防波堤築造における魚礁効果 について一御前崎港魚礁効果調査報告一, 港湾, 62 巻, 5 号, pp.73-82, 1985.

2) 浜口正志, 久保田真一, 松本朗, 半沢稔, 山本方 人 : 大きな開口部を有する新しい被覆ブロックの開 発と人エリーフへの適用, 海岸工学論文集, 54 巻, pp.961-965, 2007.

3) 川島昭二：コンブの着生基質と着生様式についての 提言, 海藻魚礁ニュース, No.14, pp.35-41, 1992.

4) 寺脇利信 : 海中砂漠緑化技術の開発 第 4 報 砂地 海底に設置したコンクリートブロック上でのアラ メ・カジメ類の生育, 電力中央研究所研究報告, U91024, 1991.

5) 西川博, 吉田範秋：人工種苗クロメ・アラメの生長 と養成について, 水産増殖, 26 巻, 1 号, pp.6-15, 1978.

6) 山本秀一, 児玉理彦, 野口雄二, 綿貫啓 : 相模湾西 部海域におけるカジメ場造成試験, 水産土木, 23 巻, 1 号, pp.13-18, 1986.

\section{VERIFICATION OF EFFECTIVENESS USING FIELD OBSERVATIONS OF NEW ECO-FRIENDLY BLOCKS}

\section{Norikazu HIROSE, Sanae SHIBATA, Nobutaka WAKABAYASHI, Satoshi NOBORU, Jun MITSUI and Masashi HAMAGUCHI}

In recent years, when ports, fishing harbours and coastal structures are constructed, it is desirable to consider the natural environment. There is a hope that seaweed will attach onto wave dissipating blocks or armor blocks, but conventional blocks do not have a shape condensive. In response to this, we have developed new wave dissipation blocks and armor blocks. These have shapes which accommodate ecofriendliness. Stability and hydraulic functions are equal to or greater than conventional blocks. Field observations were carried out to verify the eco-friendly functions of these blocks. In all the observations, large seaweed growths such as Ecklonia cava or Eisenia bicyclis were observed. Furthermore, the abalone or the tutban shells congregations were observed. Eco-friendliness of these newly designed blocks was verified. 